\title{
School Quality, Educational Inequality and Economic Growth
}

\author{
Ramesh Rao (Corresponding author) \\ Faculty of Economics \& Administration \\ University Malaya \\ 50603 Kuala Lumpur \\ Malaysia \\ Tel: 60-17-879-2159 Email: rameshdivan@yahoo.com \\ Rohana bt Jani \\ Department of Applied Statistics \\ Faculty of Economics \& Administration \\ University Malaya \\ 50603 Kuala Lumpur \\ Malaysia \\ Tel: 60-3-7967-3747Ｅmail: janir59@yahoo.com
}

\begin{abstract}
Realizing the importance of education in developing a country, many governments had begun to pay more attention in improving the education quality in their country. However whether the desired level of education quality is equally distributed is still debated on. On top of that, current literature on which level of education, either basic or tertiary education, brings greater return to the society is still inconclusive. It is not the objective of this paper to answer or add on the debate. On the other hand this paper would like to explore the relationship between school quality, namely at primary education and secondary education, and economic growth. Educational inequality at primary and secondary education would be measured with using the concept of education Gini. Using GDP as the dependent variable and regressing it with Gini coefficient of primary education and secondary education, would be able to show which level of education inequality is significant in explaining the economic growth of a country. Using Malaysian data, for the last 20 years, the relationship between education inequality of different level of education and the economic growth would be postulated.
\end{abstract}

Keywords: Inequality, Gini, economic growth

\section{Introduction}

Economics is basically the study on how limited resources are used to fulfill human's unlimited wants. There will be an opportunity costs associated with every decision made on the use and distribution of these resources. Decision makers not only have to make choices on how resources are used but also on who gets what and when. This raises the question of equality and fairness. When there is unequal distribution of resources in a country, the repercussion could be great. It could even lead to political unrest which could undermine economic growth.

The existence of a trade off between equality and growth is still disputed by many scholars. Some of the studies were subjected to criticism because of the methodology and quality of data used to derive the conclusions (Easterly, 2007). It is not the objective of this article to dispute or get involve on the debate of this trade off. Our aim is to explore the relationship between equity in education and economy growth.

One of the important ingredients for sustained economic growth is a good education system. "Education For All" (EFA) report by the World Bank (Lanzi, 2007) is in the opinion that education does influence the economic growth of many countries. To support this stand, many countries in East Asia including Japan were used as examples. Though Malaysia was not included much in the study, empirical evidence shows that Malaysia too does invest heavily on education (see Figure 1). From RM6.5 million in 1989, it increased to almost RM27 million in the year 2005. However as other countries, Malaysia too faces difficulty in distributing educational resources equally across the country. 
Education can be included as a public good in Malaysia. Although there are private schools in Malaysia, it's the government's constitutional responsibility to provide education for all children. Government has to make decisions on the distribution of educational resources. Primary and secondary education is provided to every child legally living in this country. Policy makers have to make decisions on which school gets what and how much. This leads to the question on equity which eventually will influence the economy growth of this country because students studying in the public school are future workers who will contribute to the economic growth of this country.

The distribution of educational resources to schools will not only raise the issue of equity but will also determine its quality. In other words, when distribution of resource is done equally, school quality across the nation should be same. Thus the contribution to and benefit from an economy growth in country will be even and equitable.

\section{Literature Review}

The effects of education on economic growth can be explained with using the production function and growth models (Belfield, 2000). In these models, the effects of education on economic growth are explained through the way education enhances the labour input (Romer, 1994). A Cobb-Douglas function is always used in discussion about productivity and growth. The relationship between labour and production function could be seen through the Cobb-Douglas function

$$
\mathrm{Y}_{\mathrm{t}}=K^{\alpha} H^{\beta}(\mathrm{AL})^{1-\alpha-\beta}
$$

Where $\mathrm{Y}_{\mathrm{t}}=$ per capita income

$$
\begin{aligned}
& \mathrm{H}=\text { stock of human capital } \\
& \mathrm{L}=\text { Labour } \\
& \mathrm{K}=\text { capital }
\end{aligned}
$$$$
\mathrm{A}=\text { growth coefficient }
$$

(Stevens \& Weale, 2004)

Other than labour and capital, human capital too influences $\mathrm{Y}_{\mathrm{t}}$. Human capital in a country can be accumulated through 3 means. They are schooling time, quality of education and the human capital of the parent (Glomm, 1997). Since the 1970's, the contribution of schooling time in human capital formation has been questioned. Schooling time can be measured by the enrollment rate in a country. Many countries' experiences challenge the relationship between education, human capital and economy growth. There are countries that have had increasing rate of enrollment but did not experience the economy growth they had expected. Livingstone (1997) advocated that this notion of human capital and education needs to be retooled and viewed differently. He feels that instead of just focusing on the amount of education, it is necessary to address the problem of school quality if one wants to see the actual relationship between education and human capital. This opinion is in tandem with many others such as Vinod and Kaushik (2007). Vinod \& Kaushik (2007) are also in the opinion that when the quantity and quality of human capital increases, a country's economy will grow by itself.

Many governments had begun to focus their attention on uplifting the quality of education provided. Many studies have looked into the quality of resources distributed into the educational institutions under the care of government. It is important to distinguish between school quality and quality school. School quality can be seen through the resources or input used in producing the outputs. Meanwhile quality schools are seen through the exam results or other measures of outputs. Many empirically studies done with assumption that the inputs and outputs are related proportionately. For example, when there is an increase of $10 \%$ in input, output will increase by the same margin. However, in a real world this assumption does not hold true always (Raymond, 1968).

A school quality could be measured through the resources used in educating children or students. Some of them are

$\begin{array}{ll}\text { i. } & \text { School Enrollment } \\ \text { ii. } & \text { Percent of teachers with advanced degree } \\ \text { iii. } & \text { Pupil Teacher Ratio } \\ \text { iv. } & \text { Per-pupil expenditure } \\ \text { v. } & \text { Textbook per student }\end{array}$

(Eide \& Showalter, 2005; Liu, 2001)

Horn (1993) defines the resources used in education as the input, while conversion of inputs into outputs is known as the process. Many studies had either focused on the input and output or process and output. Some of the findings of these studies are shown in Table 1. The inputs used in education also able to reflect an institution's quality. Dispersion of education resources to educational institutions would indicate the commitment of government in ensuring an equitable quality education given to its people.

Among the educational resources, teachers are one of the most researched inputs (Belfield, 2000). This could be attributed to the fact that teachers are the most mobile among the inputs used in education (Brimley \& Garfiled, 2005). 
Many teachers like to teach in high socio-economy status (SES) then low SES school. Krei (2000) found out that the chances a teacher would move or willing to teach in a low SES than high SES is 4 times lower. Because of this mobility, many governments face the problem of placing teaching thus jeopardizing the pupil-teacher ratio (PTR) in many countries. PTR is an indication of a school quality. When government manages to ensure a standard PTR in all the schools under its care then educational equity is said to exist (Yamauchi, 2005).

Educational equity is important in developing a country. Equity in education is achieved when every child gets the same level of education in terms of quality and amount (Hoxby, 1996). As mentioned earlier, education plays an important role in developing a country. If there is no equitable education then economic growth of a country will be distorted (Partridge, 1997). How and why this distortion takes place in an economy is still being debated. Some studies show that inequality will actually spur economy growth where accumulation of wealth by the rich will cause economy growth. This occurs when the "rich" will reinvest their savings back in to the economy. This notion is not agreed by some because inequality in society will cause political instability which will eventually effect the economy of a country. Inequality in society will also harm economy growth through the imbalance in human capital formation. As mentioned earlier, education plays an important role in human capital formation. Marshall (1890) had stressed the role of education in developing a country. Whatever the argument is, every government had begun to ensure that every deserving student not only gets an equal amount of education but of equal quality as well.

Equity in education can be measured through many ways. The term "equity" itself is an abstract term thus the way it is measured could influence the verdict (Stiefel \& Berne, 1981). One of the measures that is often used is the Gini coefficient. Gini coefficient is widely used by economist to show the inequality in a population (King, et.al, 2003).

\section{Methodology}

The data used in this study are obtained from the Educational Statistics Year book from the period of 1986-2005. The number of teachers and enrollments for each state is obtained from this report. Enrollments and the number of teachers reported in this report are as of $30^{\text {th }}$ June each year. The number of teachers included in the final count of PTR is based on the availability of trained teachers in the states. There are trained and untrained teachers teaching in Malaysian public schools. Trained teachers are teachers who had undergone training at Teachers Training Colleges. Although the benefits derived by students taught by trained teachers in influencing student's achievement or learning process is not proven, but it is the responsibility of every government in ensuring that every student is taught by a trained teacher (Hanushek \& Luque, 2003).

School quality is calculated through PTR. PTR is computed through the following formula

$$
\mathrm{PTR}_{\mathrm{t}}=\frac{\mathrm{E}_{\mathrm{t}}}{\mathrm{TT}_{\mathrm{t}}}
$$

Where $E_{t}$ is the number of students enrolled in the state for the year $t$; TT represents the number of trained teachers teaching in the year-t.

$$
\text { Gini }_{t}=\frac{\left(\sum_{i=1}^{N} \sum_{j=1}^{N} E_{i t} E_{j t}\left|P T R_{i t}-P T R_{j t}\right|\right)}{\left.2\left(\sum_{i=1}^{N} E_{i t}\right)^{2} \overline{P T R_{p t}}\right)}
$$

where

$$
\overline{P T R_{p t}}=\frac{\sum_{i=1}^{N} E_{i t}\left(P T R_{i t}\right)}{\sum_{i} E_{i t}}
$$

$$
\begin{aligned}
& \overline{P T R_{p t}}=\text { mean of pupil teacher-ratio for the year- } \mathrm{t} \\
& \mathrm{E}_{\mathrm{it}}=\text { number of pupils in state } i
\end{aligned}
$$

Education Gini is calculated for primary (GPS) and secondary school (GSS). Distribution is said to be equitable if the value of Gini Coefficient is less than 0.05 (Odden and Picus, 2000). In this study, the value of Gini education is converted to percentage by multiplying it with 100 . Using Odden \& Picus (2000) judgement, any value less than 5\% is assumed to be equitable.

Currently there is no measure of economic growth which is not criticized. Gross National Product and Gross Domestic 
Product are widely used in studies involving economic growth (Gilbert, 1980). In this study, economic growth is measured with GDP. GDP is divided by the total population. Per Capita GDP also reflects the well being of people living in a country (Kakwani, 1997). The data for per capita GDP is obtained from the year book published by Department of Statistics, Malaysia. The relationship between economic growth and school quality is investigated using the following regression

$$
\text { PCGDP }=\beta_{0} \mathrm{o}+\beta_{1} \text { GPS }+\beta_{2} \text { GSS }+ \text { Pop }+\varepsilon
$$

Where PCGDP is per capita gross domestic product in 1987 prices, GPS is primary school inequality, GSS is secondary school inequality and Pop is the number of population who is in the age of 0-14.

The ideal control variable should be the population size or rate who are still studying or have not entered the employment group. However due to data availability, population who are in the age group of 0 to 14 were used as a control variable. Malaysians who are in the age of 7 onwards will start attending school. Almost all of them will remain in school until the age of 17. In other words, population who are in the age of 0 to 14 , can be concluded as not employed and do not contribute much to GDP but will do so after their schooling age. The effect on GDP which is caused by the change in population strata depends on many factors. The breakdown of the population in terms of age will influence a country's GDP (Faria, et.al, 2005). How exactly it will influence, in terms relationship between population breakdown and GDP, depends on a country itself. In the case of Malaysia, the influence of population breakdown and its impact on GDP had not been much recorded. Thus, the expected sign of this control variable would not be predicted and dwelled upon.

\section{Estimation Results and discussion}

The results of Education Gini is shown in Figure 2. Using Odden \& Picus's (2000) value judgement, after the year 2000, school quality in terms of equality is improving especially at secondary schools. The same cannot be said of primary schools. This could be attributed to the fact that, in the last few years Malaysian government had been training graduate teachers who are eventually posted to secondary schools. Since 2005 onwards, graduate teachers are also posted to primary schools. Prior to this, non-graduate teachers are sent to primary schools while graduate teachers are sent to secondary schools only.

When there is influx of students in any public school, it will cause the PTR to change. The sudden increase in enrollments can outstretch a state's capacity to provide teachers and maintain the PTR (Garnier \& Schafer, 2006). This effect will be felt in primary schools followed by secondary schools. A student is required to undergo at least 6 years of primary education before he/she can further in a secondary school. This enables education planners to get teachers ready for secondary school, where 6 years is long enough to increase the supply of teachers. This explains why the fluctuation of the PTR in primary school appears to be greater than in secondary schools!

The objective in this study is to see the relationship between school inequality and economic growth. The estimated result is shown in Table 2. Adjusted $\mathrm{R}^{2}$ of 0.88 and an F-Statistic that is significant shows that the overall goodness of fit is satisfactory. The non-significant of Jarque-Bera shows that the null hypothesis of normality is not rejected (Diebold, 2004). Since the p-value of White test is more than 0.05 , then the null hypothesis of homoscedasticty is not rejected. Multicollinearity among the variables is also tested and none of them exceed the value of 0.8 which is recommended by Gujarati (1999).

The interpretation of the results is fairly straightforward. The sign of the constant can be either positive or negative. The slope parameters of inequality conform to the null hypothesis of a negative relationship between inequality and economic growth. When inequality in schools increases it will lead to a reduction of per capita GDP in the society. When primary school inequality increases by 1 percent, per capita GDP will reduce by RM149. Meanwhile when secondary school inequality increases by 1 percent then per capita GDP will reduce by RM323. However, only the secondary school inequality fulfills the $10 \%$ significance criterion.

The significant of secondary education in explaining the per capita GDP in a way contradicts to what was taught earlier of the importance of primary school over secondary school (Aromolaran, 2006). This results shows that secondary school is more important in explaining the per capita GDP in Malaysia. This could be attributed to the fact that only basic education such as Reading, Writing and Mathematics, which are taught in primary schools is not sufficient for a country such as Malaysia to fulfill its labour needs. Malaysian industrialization policies which had transformed the country's economy from agriculture dependent to technology dependent needs skilled labour force. Basic reading, writing and mathematics skills alone are unable to prepare an individual for this task. Subjects such as "Information Technology" and 'Living Skills" which are taught in secondary schools would prepare students to meet the nation's labour demand. This explains why when there is inequality in secondary schools, per capita GDP of Malaysia is affected.

\section{Conclusion}


Education is important in enhancing the stock of human capital in an economy. The mere providing of an education is not sufficient in improving an economy. This initial study shows that, equality in education in terms of quality will influence a country's economic growth. This study also reveals the importance of secondary education. But this does not mean that primary education could be neglected. It is important that governments should improve the distribution of education resources among the secondary schools but it should not be at the expense of primary education. The other point which should be taken and explored further is whether the findings of this study will stand if carried out in a country with different economy activities such as agriculture based economies.

\section{References}

Aromolaran, A. B. (2006). "Estimates of Mincerian Returns to Schooling in Nigeria." Oxford Development Studies 34(2): 265-292.

Belfield, C. R. (2000). Economic Principles for Education. Bodmin, Cornwall, MPG Books Ltd.

Brimley, V. J. and R. R. Garfield (2005). Financing Education: In A Climate of Change. USA, Pearson.

Diebold, F. X. (2004). Elements of Forecasting. Canada, Thomson South-Western.

Easterly, W. (2007). "Inequality does cause underdevelopment: Insights from a new instrument." Journal of Development Economics 84(2): 755-776.

Eide, E. R. and M. H. Showalter (2005). "Does Improving School Quality Reduce The Probability Of Unemployment?" Contemporary Economic Policy 23(4): 578-584.

Faria, J. O. R., M. A. L. N-Ledesma, et al. (2006). "Population and Income: Is There a Puzzle?" Journal of Development Studies 42(6): 909-917.

Garnier, M. and M. Schafer (2006). "Educational Model and Expansion of Enrollments in Sub-Saharan Africa." Sociology of Education 79(2): 153-175.

Glomm, G. (1997). "Parental choice of human capital investment." Journal of Development Economics 53(1): 99-114.

Gujarati, D. (1999). Essentials of Econometrics. Boston, Mc Graw Hill.

Hanushek, E. A. (1986). "The Economics of Schooling: Production and Efficiency in Public Schools." Journal of Economic Literature 24(3): 1141-1177.

Hanushek, E. A. and J. A. Luque (2003). "Efficiency and equity in schools around the world " Economics of Education Review 22(5): 481-502.

Horn, R. V. (1993). Statistical Indicators For The Economic \& Social Sciences, Cambridge University Press.

Hoxby, C. M. (1996). "Are Efficiency and Equity in School Finance Substitutes or Complements?" Journal of Economic Perspectives 10(4): 51-72.

Kakwani, N. (1997). "Growth rates of per capita income and aggregate welfare: An international comparison." Review of Economics \& Statistics 79(2): 201-211.

King, R. A., A. D. Swanson, et al. (2003). School Finance: Achieving High Standards With Equity And Efficiency. Boston, Allyn and Bacon.

Krei, M. S. (2000). Teacher Transfer Policy and the Implications for Equity in Urban School Districts. American Educational Researchers Association, New Orleans, American Educational Researchers Association.

Lanzi, D. (2007). "Capabilities, human capital and education." Journal of Socio-Economics 36(3): 424-435.

Lin, C.-H. A. (2007). "Education Expansion, Educational Inequality, And Income Inequality: Evidence From Taiwan, 1976-2003." Social Indicators Research 80: 601-615.

Liu, A. Y. C. (2001). "Flying Ducks? Girls' Schooling in Rural Vietnam." Asian Economic Journal 15(4): 385-404.

Livingstone, D. W. (1997). "The Limits Of Human Capital Theory: Expanding Knowledge, Informal Learning And Underemployment." Policy Options.

Marshall, A. (1890). Principles of Economics: An Introductory Volume. London, The Macmillan Press Ltd.

Odden, A. R. and L. O. Picus (2000). School Finance: A Policy Perspectives. New York, McGraw-Hill.

Raymond, R. (1968). "Determinants Of The Quality Of Primary And Secondary Public Education In West Virginia." Journal of Human Resources 3(4): 450-470.

Romer, P. M. (1994). "The Origins of Endogenous Growth." Journal of Economic Perspectives 8(1): 3-22.

Stevens, P. and M. Weale, Eds. (2004). Education and economic growth. International Handbook on the Economics of Education. USA, Edward Elgar Publishing Ltd. 
Stiefel, L. and R. Berne (1981). "The Equity Effects of State School Finance Reforms: A Methodological Critique and New Evidence." Policy Science 13: 75-98.

Vinod, H. D. and S. K. Kaushik (2007). "Human Capital And Economic Growth: Evidence From Developing Countries." The American Economist 51(1).

Yamauchi, F. (2005). "Race, equity, and public schools in post-Apartheid South Africa: Equal opportunity for all kids." Economics of Education Review 24(2): 213-233

Table 1. Summary of estimated expenditure parameter coefficients from 147 Studies of Educational Production Function

\begin{tabular}{|l|c|c|c|c|c|c|c|}
\hline \multirow{2}{*}{ Input } & \multirow{2}{*}{$\begin{array}{c}\text { Number } \\
\text { of } \\
\end{array}$} & \multicolumn{2}{|c|}{$\begin{array}{c}\text { Statistically } \\
\text { Studies }\end{array}$} & \multicolumn{4}{|c|}{ Statistically Insignificant } \\
\cline { 3 - 8 } & & + & - & Total & + & - & Unknown Sign \\
\hline Pupil Teacher Ratio & 112 & 9 & 14 & 89 & 25 & 43 & 21 \\
\hline Teacher Education & 106 & 6 & 5 & 95 & 26 & 32 & 37 \\
\hline Teacher Experience & 109 & 33 & 7 & 69 & 32 & 22 & 15 \\
\hline Teacher Salary & 60 & 9 & 1 & 50 & 15 & 11 & 24 \\
\hline Expenditures/pupils & 65 & 13 & 3 & 49 & 25 & 13 & 11 \\
\hline
\end{tabular}

Source: Hanushek, 1986

Table 2. Per Capita GDP Parameter Estimation Results

\begin{tabular}{|c|c|c|c|c|}
\hline Variable & Coefficient & Std. Error & t-Statistic & Prob. \\
\hline $\mathrm{C}$ & -8840.66 & 1596.52 & -5.53 & 0.00 \\
\hline GPS & -149.08 & 211.27 & -0.70 & 0.49 \\
\hline GSS & -323.28 & 185.74 & -1.74 & $0.10^{++}$ \\
\hline Pop & 2.25 & 0.21 & 10.68 & 0.00 \\
\hline R-squared & 0.90 & \multicolumn{2}{|c|}{ Mean dependent var } & 8216.04 \\
\hline Adjusted R-squared & 0.88 & \multicolumn{2}{|c|}{ S.D. dependent var } & 1425.58 \\
\hline S.E. of regression & 486.00 & \multicolumn{2}{|c|}{ F-statistic } & $41.55^{*}$ \\
\hline Sum squared resid & 3070655 & \multicolumn{2}{|c|}{ Prob(F-statistic) } & 0.00 \\
\hline Log likelihood & -127.00 & \multicolumn{2}{|c|}{ White Heterosced } & 3.80 \\
\hline Jarque-Bera & 0.52 & \multicolumn{2}{|c|}{ White Chi square prob } & 0.70 \\
\hline Jarque-Bera Prob & 0.76 & & & \\
\hline
\end{tabular}

* Statistical significance level at 5\% level

** Statistical significance level at $10 \%$ level 


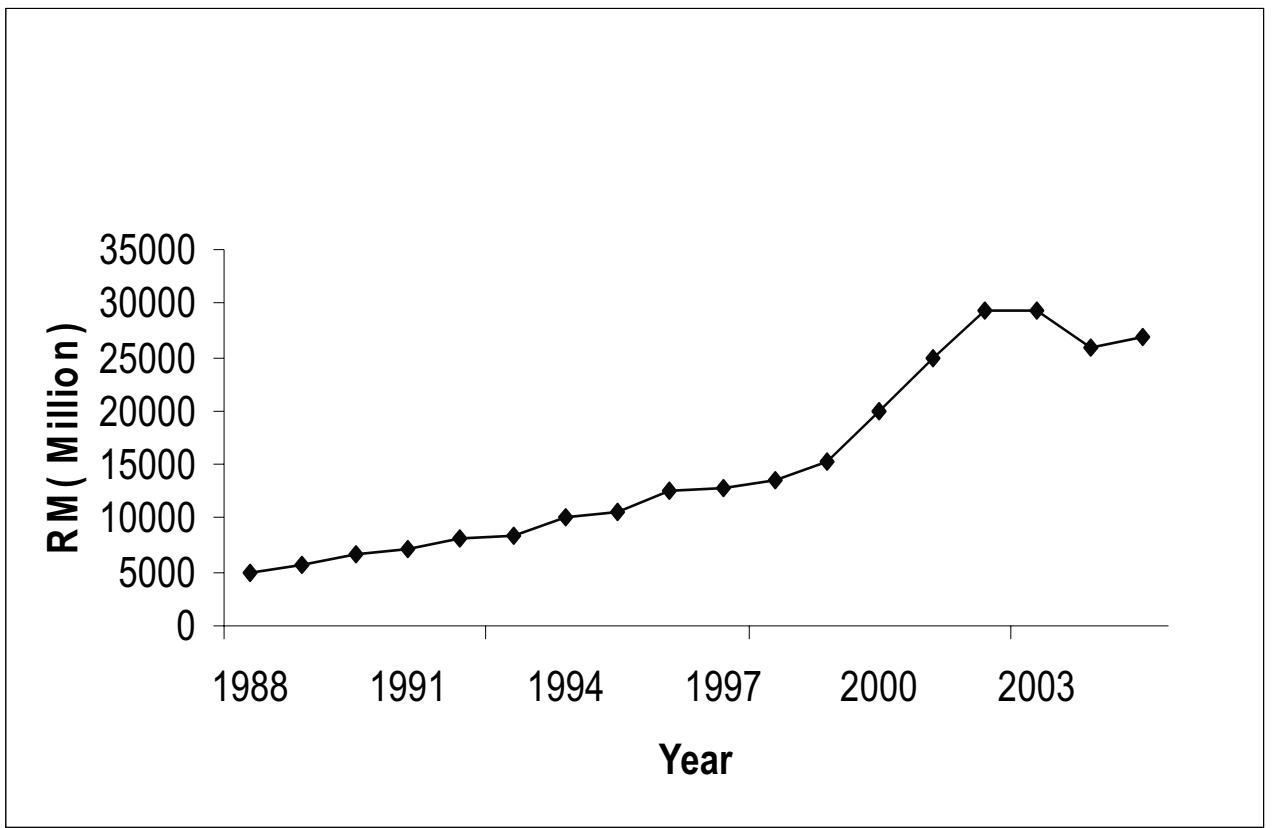

Figure 1. Amount of expenditure on education by Central Government Malaysia (1988-2005) Source:www.adb.org/statistics (26 November 2006)

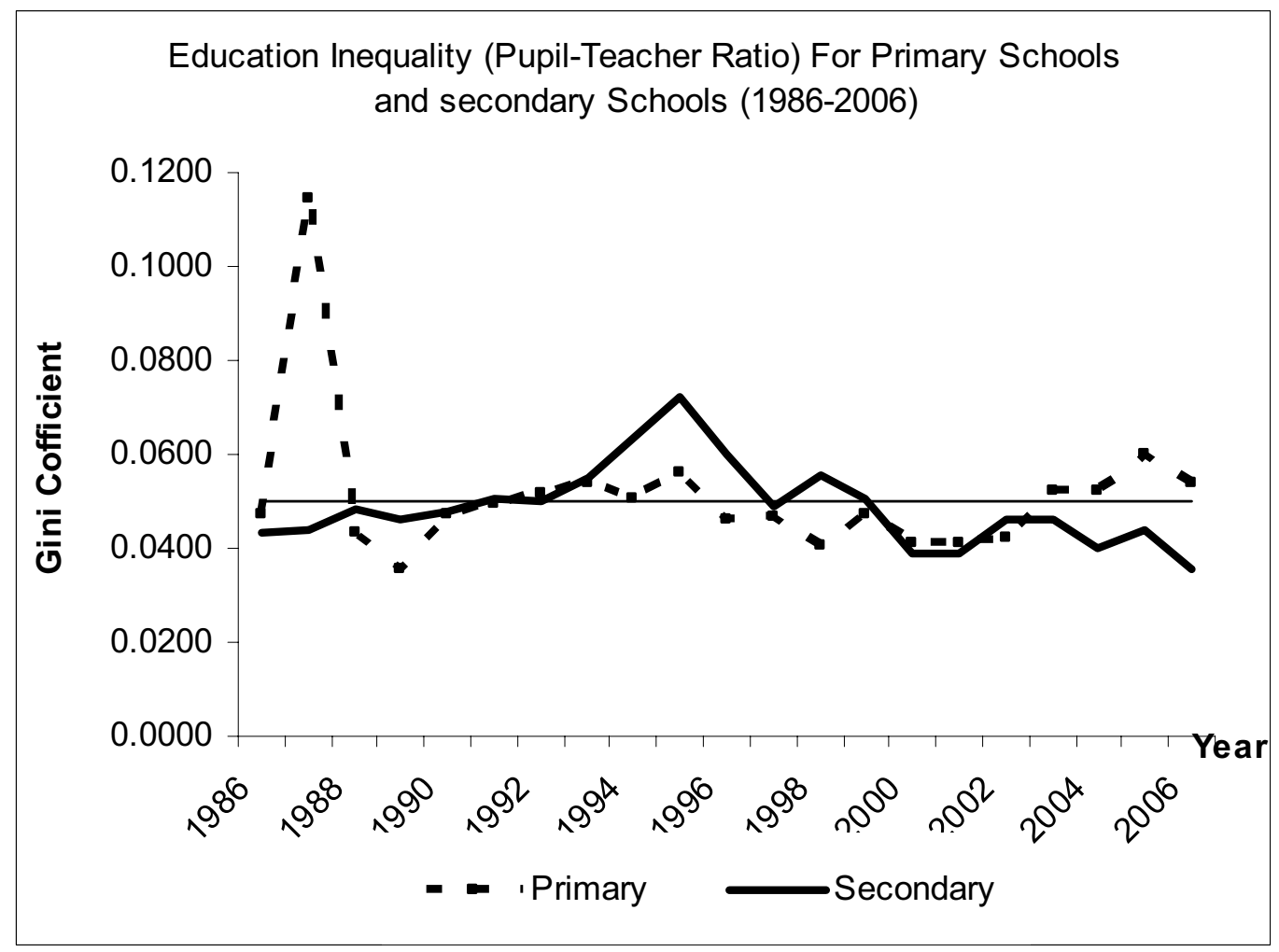

Figure 2. Education Inequality (Pupil Teacher ratio) for Primary Schools and secondary Schools (1986-2006) 